\title{
Pituitary Adenoma Apoplexy in an Adolescent: A Case Report and Review of the Literature
}

\author{
Hero Zijlker ${ }^{1}$, Sebastian Schagen ${ }^{1}$, Jan Maarten Wit ${ }^{1}$, Nienke Biermasz ${ }^{2}$, Wouter van Furth ${ }^{3}$, Wilma Oostdijk ${ }^{1}$ \\ ${ }^{1}$ Leiden University Medical Center, Department of Pediatrics, Leiden, The Netherlands \\ 'Leiden University Medical Center, Department of Medicine, Division of Endocrinology, Leiden, The Netherlands \\ ${ }^{3}$ Leiden University Medical Center, Department of Neurosurgery, Leiden, The Netherlands
}

\section{What is already known on this topic?}

Pituitary apoplexy (PA) is a rare clinical syndrome in adolescents that can cause a life-threatening situation. PA is frequently seen in nonfunctioning adenomas and often results in headache and visual impairments.

\section{What this study adds?}

Our study is to help physicians in differentiating between a PA and a pituitary abscess, to create an overview of the possible clinical symptoms seen in PA, and to create awareness for a possible adrenocorticotropic hormone-deficiency.

\section{Abstract}

We present a 13-year-old boy who was admitted with complaints of a state of progressive sleepiness and a sudden headache with vomiting and fever. Laboratory testing showed hypoglycemia, multiple pituitary hormonal deficiencies, and an elevated C-reactive protein level. A cranial magnetic resonance imaging (MRI) showed an opaque sphenoid sinus and an intrasellar mass suggesting hemorrhage, so that we suspected pituitary apoplexy (PA) originating from a non-functioning adenoma, although a pituitary abscess could not completely be excluded. The boy was treated with antibiotics, hydrocortisone, and levothyroxine. Due to his rapid clinical improvement, no surgery was performed and we considered the diagnosis of PA as confirmed. At follow-up, the MRI scan showed a small residual lesion. Pituitary deficiencies of growth hormone, adrenocorticotropic hormone (ACTH), thyroid-stimulating hormone, and vasopressin persisted. A literature search of all well-documented cases of PA in children or adolescents ( $n=30,13$ boys and 17 girls) indicated that this condition is rare below 20 years of age but must be considered when a patient experiences headache with or without visual disturbances, even in the presence of clinical and laboratory signals suggestive of pituitary abscess. MRI neuroimaging is helpful in the differential diagnosis. In both conditions, the possibility of ACTH deficiency should always be considered, investigated, and treated. In cases without severe neuro-ophthalmological deficits and/or with a rapid and positive response to acute medical management, one can abstain from surgical treatment.

Keywords: Pituitary adenoma, apoplexy, panhypopituitarism, adolescents, pituitary abscess, headache, magnetic resonance imaging

\section{Introduction}

Neoplasms of the pituitary gland are extremely rare in childhood and adolescence (1:1.000,000) (1). Of all pituitary neoplasms, less than $10 \%$ are diagnosed in children and adolescents. Most of these are craniopharyngiomas (80$90 \%$ ) and relatively few (3\% of all intracranial neoplasms) are adenomas. Of all adenomas in patients younger than 20 years, approximately $97 \%$ secrete hormones and $16 \%$ develop pituitary apoplexy (PA) (2).

PA is a clinical syndrome caused by hemorrhage or infarction of the pituitary gland and is predominantly seen in patients with pituitary adenomas, probably due to their relatively high metabolism, limited blood flow, and high 
intratumoral pressure when compared to other primary central nervous system tumors (3). PA occurs relatively often in large macroadenomas (4). Since non-functioning adenomas (NFAs) are on average larger than endocrine active adenomas, PA is relatively more frequently observed in NFAs $(2,4)$. The presenting symptoms include sudden and severe headache, visual disturbances, and various neurological signs (4). In adults, PA is more common in males between 50-69 years and precipitating factors include angiography, cardiac surgery, anticoagulant therapy, and dynamic hormonal testing or gonadotropin-releasing hormone (GnRH) agonist treatment. However, little is known about this condition in patients younger than 20 years.

In 1972, Dawson and Kothandaram (5) were the first to describe an adolescent with PA. Since then, only a few case reports and individual cases extracted from larger case series have been reported in the literature. In 2015, Jankowski et al (6) presented a case series of nine adolescents with PA, comparing symptomatology, neuroimaging, pathology, and outcomes to those in adults.

In this paper, we report a case of a 13-year-old boy presenting with sudden and severe headache. Additional investigations suggested PA originating from an non-functioning adenoma (NFA), although initially a pituitary abscess [accounting for less than $1 \%$ of all pituitary lesions (7)] could not be completely excluded. We reviewed the literature and summarize the clinical, biochemical, and imaging characteristics of all reported cases of PA in patients younger than 20 years. Pediatricians should be aware that this condition which is frequently accompanied by adrenocorticotropic hormone (ACTH) deficiency, although extremely rare, can occur in children and adolescents and that the differential diagnosis with pituitary abscess can be difficult.

\section{Case Report}

A 13-year-old boy, with an uninformative previous medical history, presented at the pediatric clinic of a general hospital with complaints of severe fatigue which had lasted for several months. Four days prior to admission, he had become progressively sleepy and experienced a sudden and severe stabbing frontal headache with vomiting and phonophobia. At physical examination, he had a normal level of consciousness, fever up to 38 degrees Celsius, and no neurological abnormalities. He had no visual disturbances and normal extra-ocular movements. His linear growth and pubertal development had been unremarkable; at admission, his height standard deviation score (SDS) was 0.0 (8). His body mass index was $20 \mathrm{~kg} / \mathrm{m}^{2}$ (+1.0 SDS) (9) and Tanner stage was G3P3A2 with testes of $12 \mathrm{~mL}$ (assessed with the
Prader orchidometer). Initial laboratory results demonstrated a normal white blood cell count $\left(9.2 \times 10^{9} / \mathrm{L} ; 54 \%\right.$ neutrophils), an elevated serum C-reactive protein (CRP) $(201 \mathrm{mg} / \mathrm{L})$ and hypoglycemia $(2.8 \mathrm{mmol} / \mathrm{L})$. Despite normal neurological examination, increased intracranial pressure due to a brain tumor or abscess was considered because of the severe headache and vomiting. For this reason, broad-spectrum antibiotics were immediately administered intravenously and he was referred to our academic hospital.

Magnetic resonance imaging (MRI) of the cerebrum showed a sellar mass with suprasellar extension $(2.5 \times 2.0$ $\mathrm{cm}$ ) and slight optic chiasm compression (Figure 1). The mass appeared heterogeneously hyperintense on T1weighted imaging (T1WI) and hypointense to isointense on T2-weighted imaging (T2WI). Also sphenoid sinus mucosal thickening and rim enhancement of the mass after gadolinium contrast were noted. These MRI findings were highly suggestive of hemorrhage that most likely originated from a pre-existing pituitary adenoma.

The endocrine investigations (Table 1) demonstrated central hypothyroidism, hypocortisolism, and hypogonadism, as well as low serum insulin-like growth factor (IGF)-I and IGF

Table 1. Hormonal values of our case at presentation and 3 months later

\begin{tabular}{|c|c|c|c|}
\hline & $\begin{array}{l}\text { At } \\
\text { presentation }\end{array}$ & $\begin{array}{l}\text { After } 3 \\
\text { months }\end{array}$ & $\begin{array}{l}\text { Normal } \\
\text { values }\end{array}$ \\
\hline LH (U/L) & 1.3 & 2.1 & $2.0-9.0$ \\
\hline FSH (U/L) & 1.8 & 3.8 & $1.5-12.5$ \\
\hline ACTH (8 a.m.) (ng/L) & 10 & & $0-75$ \\
\hline Cortisol (8 a.m.) ( $\mu \mathrm{mol} / \mathrm{L})$ & 0.213 & 0.386 & $0.1-0.6$ \\
\hline $\begin{array}{l}\text { Cortisol in ACTH-test } \\
\left(0.58 \mathrm{ug} / \mathrm{m}^{2}\right)\end{array}$ & $\begin{array}{l}0.036^{*} \rightarrow \\
0.321^{*} *\end{array}$ & & $>0.50 * *$ \\
\hline TSH (mU/L) & 0.134 & 0.318 & $0.3-4.8$ \\
\hline $\mathrm{fT}_{4}(\mathrm{pmol} / \mathrm{L})$ & 6.6 & 15.9 & $12-22$ \\
\hline hGH $(\mu g / L)$ & 0.73 & 0.21 & $0.00-2.42$ \\
\hline IGF-I (nmol/L) & 5.2 & 15.9 & $18.5-74.1$ \\
\hline IGF-I (SDS) & -4.1 & -2.4 & \\
\hline IGFBP-3 (mg/L) & 2.1 & 5.4 & $2.6-6.3$ \\
\hline Prolactin $(\mu \mathrm{g} / \mathrm{L})$ & 2.4 & 3.2 & $4.0-15.0$ \\
\hline Testosterone (nmol/L) & $<0.1$ & 8.9 & $8-31$ \\
\hline Osmolarity (mOsmol/kg) & 354 & 573 & $50-1200$ \\
\hline Sodium (mmol/L) & 137 & 143 & $136-144$ \\
\hline Potassium (mmol/L) & 3.9 & 4.2 & $3.6-4.8$ \\
\hline
\end{tabular}

*At baseline, **after 30 minutes

LH: luteinizing hormone, FSH: follicle-stimulating hormone, ACTH: adrenocorticotropic hormone, hGH: human growth hormone, IGF-I: insulinlike growth factor, IGFBP-3: insulin-like growth factor binding protein-3, SDS: standard deviation scores, $\mathrm{fT}_{4:}$ free thyroxine 
binding proteins-3 levels suggestive of growth hormone $(\mathrm{GH})$ deficiency. A stress dose of hydrocortisone was immediately administered followed by substitution with hydrocortisone and levothyroxine. We considered PA originating from an NFA most likely, based on the specific MRI findings.

Because we could not completely exclude pituitary abscess, immediate surgical intervention was considered. However, rapid clinical improvement was noted after administration of broad-spectrum antibiotics, and hydrocortisone was started. One day after initiation of treatment, the fever disappeared and CRP levels gradually declined to $48 \mathrm{mg} / \mathrm{L}$ on the fourth post-treatment day. CRP levels were completely normalized after 2 weeks. Surgery was eventually not performed due to the boy's rapid clinical improvement, the sella enlargement, which is unusual for pituitary abscess, and the sphenoid sinus mucosal thickening seen on the MRI, which suggested a possible infectious process on the surgical route. The combination of MRI findings and clinical course has made the diagnosis of PA virtually certain, although not histologically confirmed. Remarkably, diabetes insipidus (DI) developed three days after admission despite conservative treatment.

The patient was discharged after five days with oral broadspectrum antibiotics, hydrocortisone, levothyroxine, and vasopressin. A small residual lesion was seen on the MRI three months later (Figure 1), which resolved after 6

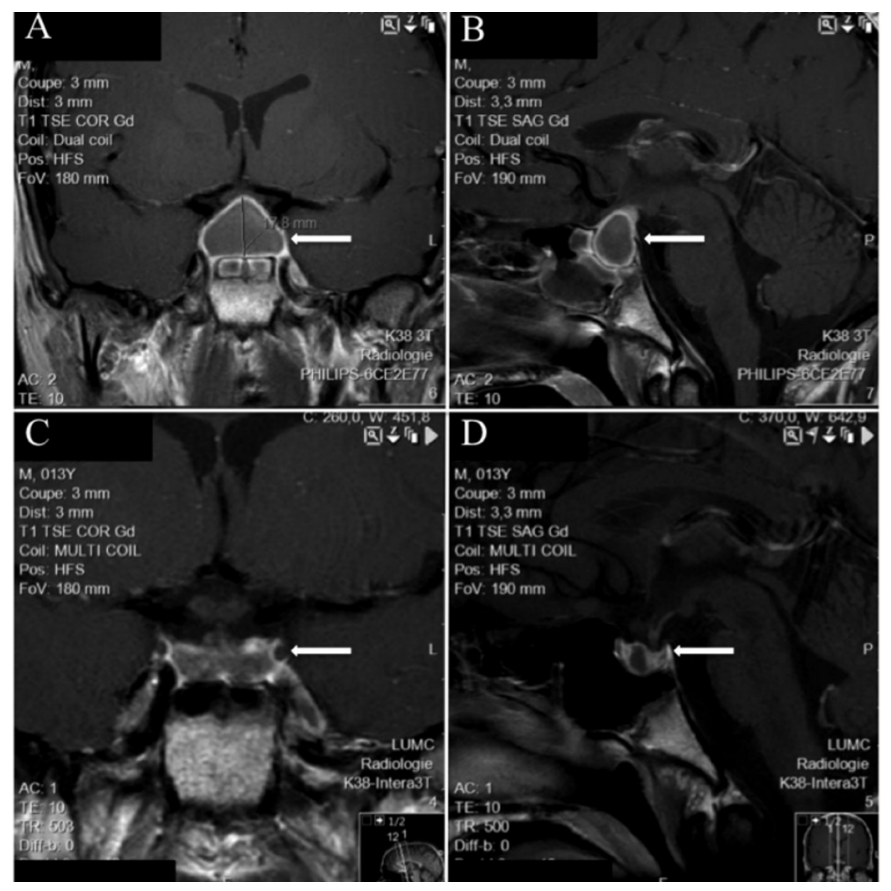

Figure 1. Magnetic resonance imaging: T1-weighted imaging. At presentation: coronal (A) and sagittal (B) view showing rim enhancement and sphenoid sinus mucosal thickening. Three months later: coronal (C) and sagittal (D) view showing substantial mass reduction months. The thyroid-stimulating hormone (TSH) and ACTH deficiencies persisted. GH deficiency was diagnosed by a very low $(\mathrm{GH}$ peak $0.9 \mathrm{ug} / \mathrm{L}$ ) response to $\mathrm{GH}$ stimulation tests, so that $\mathrm{GH}$ substitution was started. The pituitarygonadal axis was not affected (normal pubertal GnRH test) and puberty progressed normally. Genetic evaluation showed no abnormalities in the MEN1 gene.

\section{Literature Search}

A literature search was performed in databases Pubmed, Embase, Web of Science, Medline, and Cochrane to identify all cases of PA originating from an adenoma in patients younger than 20 years. Only publications written in English were included.

Cases found in larger case series with no or scarce individual descriptions were excluded $(n=36)(2,10,11)$. This resulted in 30 cases published between 1972 and 2016: 16 case reports and 14 cases extracted from 6 case series (Table 2) $(5,6,11,12$, $13,14,15,16,17,18,19,20,21,22,23,24,25,26,27,28,29,30)$. The total group consisted of 13 boys and 17 girls with a mean age of 15.3 years (range 6-19 years, median 16 years).

\section{Discussion}

PA in children and adolescents is a rare entity that requires rapid and adequate treatment to prevent a life-threatening situation. Based upon our literature search, various aspects are discussed.

\section{Non-Functioning Pituitary Adenomas and Pituitary Apoplexy}

Only $3 \%$ of all pituitary adenomas in patients younger than 20 years are NFAs (2). This low percentage can be explained by the slow growth of pituitary adenomas and data suggesting that $85-90 \%$ of normal pituitary gland and optic chiasm have to be compromised to develop endocrine insufficiencies and visual deficits, respectively (31).

So far, only four extensively described cases of patients younger than 20 years with PA originating from a NFA have been published $(13,18,22,23)$. Based upon these data, we conclude that PA originating from a NFA is an extremely rare entity in this age group, despite the fact that PA is likely to occur in NFAs.

\section{Adrenocorticotropic Hormone Deficiency}

A corticotropic deficiency can lead to serious hemodynamic instabilities causing a life-threatening situation and this was seen in 50-80\% of the adult patients with PA (4). No accurate data are available for determining the prevalence of corticotropic deficiencies in children and adolescents with PA. However, $43 \%(5,12,13,14,16,17,18,19,22,23,25$, $27,29)$ of the reported cases received steroid replacement 
Table 2. Summary of clinical and pathological characteristics of cases younger than 20 years with pituitary apoplexy

\begin{tabular}{|c|c|c|c|c|c|}
\hline $\begin{array}{l}\text { Case } \\
\text { no. }\end{array}$ & $\begin{array}{l}1^{\text {st }} \text { Author } \\
\text { (reference) } \\
\text { Year of } \\
\text { publication }\end{array}$ & $\begin{array}{l}\text { Age } \\
\text { Sex }\end{array}$ & Clinical signs and symptoms & Visual disturbances & $\begin{array}{l}\text { Endocrine function } \\
\text { and symptoms }\end{array}$ \\
\hline 1 & $\begin{array}{l}\text { Dawson and } \\
\text { Kothandaram } \\
\text { (5) } 1972\end{array}$ & $17 \mathrm{~F}$ & $\begin{array}{l}\text { Headache, fever, URI, confusion } \\
\text { (1 week), neck stiffness, } \\
\text { hemiparesis, unconscious }\end{array}$ & $\begin{array}{l}\text { Decreased visual acuity, nerve III } \\
\text { and VI palsy, acute eyelid edema, } \\
\text { papilledema }\end{array}$ & Amenorrhea \\
\hline 2 & $\begin{array}{l}\text { Rovit and Fein } \\
\text { (20) } 1972\end{array}$ & $18 \mathrm{~F}$ & $\begin{array}{l}\text { Headache, lethargy, } \\
\text { moribund ( } 6 \text { hours, after } \\
\text { pneumoencephalography), neck } \\
\text { stiffness }\end{array}$ & $\begin{array}{l}\text { Decreased visual acuity (6 hours), } \\
\text { nerve III-V palsy }\end{array}$ & $\begin{array}{l}\text { Cushing’s syndrome, } \\
\text { total adrenalectomy, } \\
\text { galactorrhea }\end{array}$ \\
\hline 3 & $\begin{array}{l}\text { Sakalas et al (21) } \\
1973\end{array}$ & $6 \mathrm{M}$ & $\begin{array}{l}\text { Headaches, fever ( } 18 \text { months), } \\
\text { lethargic and sleepy ( } 3 \text { weeks), } \\
\text { neck stiffness }\end{array}$ & $\begin{array}{l}\text { Photophobia ( } 18 \text { months), progressive } \\
\text { visual loss ( } 3 \text { weeks), blindness, } \\
\text { dilated pupils and unresponsive to } \\
\text { light }\end{array}$ & Gigantism \\
\hline 4 & $\begin{array}{l}\text { Arisaka et al } \\
(12) \\
1983\end{array}$ & $11 \mathrm{M}$ & $\begin{array}{l}\text { Headache, vomiting, and fever } \\
\text { (12 days) }\end{array}$ & $\begin{array}{l}\text { Decreased visual acuity ( } 12 \text { days), } \\
\text { bitemporal hemianopsy and bilateral } \\
\text { optic atrophy }\end{array}$ & $\begin{array}{l}\text { Gigantism, precocious } \\
\text { puberty, galactorrhea }\end{array}$ \\
\hline 5 & $\begin{array}{l}\text { Kaplan et al (15) } \\
1983\end{array}$ & $17 \mathrm{~F}$ & Headache (chronic) & None & $\begin{array}{l}\text { Amenorrhea, } \\
\text { galactorrhea }\end{array}$ \\
\hline 6 & $\begin{array}{l}\text { Kaplan et al (15) } \\
1983\end{array}$ & $15 \mathrm{~F}$ & Headache (chronic) & None & $\begin{array}{l}\text { Growth faltering, } \\
\text { pubertal delay }\end{array}$ \\
\hline 7 & $\begin{array}{l}\text { Lever et al } \\
\text { (27) } 1986\end{array}$ & $19 \mathrm{~F}$ & $\begin{array}{l}\text { Headache, nausea, vomiting } \\
\text { fever (following TRH } \\
\text { stimulation), neck stiffness }\end{array}$ & $\begin{array}{l}\text { Photophobia, diplopia (following TRH } \\
\text { stimulation) }\end{array}$ & $\begin{array}{l}\text { Gigantism, acromegaly, } \\
\text { irregular menstruation, } \\
\text { galactorrhea }\end{array}$ \\
\hline 8 & $\begin{array}{l}\text { Pozzati et al (26) } \\
1987\end{array}$ & $15 \mathrm{M}$ & $\begin{array}{l}\text { Headache, nausea, vomiting, } \\
\text { lethargy, neck stiffness }\end{array}$ & $\begin{array}{l}\text { Diplopia, nerve III and VI palsy, } \\
\text { central facial weakness }\end{array}$ & None \\
\hline 9 & $\begin{array}{l}\text { Vidal et al } \\
\text { (23) } 1992\end{array}$ & $16 \mathrm{~F}$ & $\begin{array}{l}\text { Headache, stupor, neck stiffness } \\
\text { (1 day) }\end{array}$ & Photophobia (1 day) & $\begin{array}{l}\text { Amenorrhea } \\
(5 \text { months), } \\
\text { panhypopituitarism }\end{array}$ \\
\hline 10 & $\begin{array}{l}\text { Mizutani et al } \\
\text { (18) } 1993\end{array}$ & $11 \mathrm{M}$ & 'Visual symptoms' & $\begin{array}{l}\text { Gradual decrease of visual acuity for } 2 \\
\text { years, bitemporal hemianopsy }\end{array}$ & None \\
\hline 11 & $\begin{array}{l}\text { Kulah et al } \\
\text { (17) } 1995\end{array}$ & $17 \mathrm{M}$ & $\begin{array}{l}\text { Headaches, mild degree of } \\
\text { mental dullness ( } 4 \text { months) }\end{array}$ & None & $\begin{array}{l}\text { Growth faltering, } \\
\text { pubertal delay, } \\
\text { hypopituitarism }\end{array}$ \\
\hline 12 & $\begin{array}{l}\text { Sugita et al } \\
\text { (11) } 1995\end{array}$ & $14 \mathrm{~F}$ & Headache (3 weeks) & $\begin{array}{l}\text { Progressive bilateral visual loss ( } 2 \\
\text { weeks), decreased bilateral visual } \\
\text { activities, bitemporal hemianopsy }\end{array}$ & None \\
\hline 13 & $\begin{array}{l}\text { Pinto et al } \\
\text { (19) } 1998\end{array}$ & $14 \mathrm{~F}$ & $\begin{array}{l}\text { Headache, fever, vomiting, } \\
\text { asthenia (after } 6 \text { months of } \\
\text { bromocriptine) }\end{array}$ & Diplopia & $\begin{array}{l}\text { Amenorrhea, } \\
\text { hypopituitarism }\end{array}$ \\
\hline 14 & $\begin{array}{l}\text { Dourakis et al } \\
\text { (13) } 2002\end{array}$ & $15 \mathrm{M}$ & $\begin{array}{l}\text { Headache, vertigo, fever ( } 4 \\
\text { days), neck stiffness }\end{array}$ & Photophobia (4 days) & $\begin{array}{l}\text { Growth faltering, } \\
\text { pubertal delay, } \\
\text { hypopituitarism }\end{array}$ \\
\hline 15 & $\begin{array}{l}\text { Rotman-Pikielny } \\
\text { et al (28) } 2003\end{array}$ & $19 \mathrm{~F}$ & $\begin{array}{l}\text { Headache, fever ( } 2 \text { days after } \\
\text { CRH stimulation), nausea, } \\
\text { vomiting, neck stiffness }\end{array}$ & $\begin{array}{l}\text { Ptosis, nerve III palsy, diplopia, } \\
\text { photophobia }\end{array}$ & $\begin{array}{l}\text { Cushing’s syndrome, } \\
\text { amenorrhea, } \\
\text { galactorrhea, fatigue }\end{array}$ \\
\hline 16 & $\begin{array}{l}\text { Knoepfelmacher } \\
\text { et al (16) } 2004\end{array}$ & $17 \mathrm{M}$ & $\begin{array}{l}\text { Headache, nausea, vomiting, } \\
\text { asthenia (after } 1 \text { year of } \\
\text { cabergoline) }\end{array}$ & None & $\begin{array}{l}\text { Pubertal delay, } \\
\text { hypopituitarism }\end{array}$ \\
\hline 17 & $\begin{array}{l}\text { Satyarthee and } \\
\text { Mahapatra } \\
\text { (22) } 2005\end{array}$ & $13 \mathrm{M}$ & $\begin{array}{l}\text { Headache (6 hours), meningeal } \\
\text { irritability }\end{array}$ & $\begin{array}{l}\text { Decreased visual acuity (6 hours), } \\
\text { bitemporal hemianopsy }\end{array}$ & Normal hormonal status \\
\hline
\end{tabular}


Table 2. Continued

\begin{tabular}{|c|c|c|c|c|c|}
\hline 18 & $\begin{array}{l}\text { Kamboj et al } \\
\text { (14) } 2005\end{array}$ & $18 \mathrm{M}$ & $\begin{array}{l}\text { Headache, nausea, lethargy, } \\
\text { disoriented, fever ( } 3 \text { days) }\end{array}$ & $\begin{array}{l}\text { Unequal but reactive } \\
\text { pupils, acutely } \\
\text { deterioration of vision } \\
\text { and pupillary responses }\end{array}$ & Hypopituitarism \\
\hline 19 & $\begin{array}{l}\text { Balarini Lima et al } \\
\text { (30) } 2008\end{array}$ & $15 \mathrm{~F}$ & $\begin{array}{l}\text { Headache (after } 32 \text { weeks of } \\
\text { cabergoline) }\end{array}$ & $\begin{array}{l}\text { Left-sided blindness, loss } \\
\text { of left visual field }\end{array}$ & $\begin{array}{l}\text { Puberty arrest, amenorrhea, } \\
\text { hypogonadotrophic } \\
\text { hypogonadism }\end{array}$ \\
\hline 20 & $\begin{array}{l}\text { Wang et al } \\
\text { (24) } 2011\end{array}$ & $15 \mathrm{~F}$ & 'Endocrine symptoms' & None & $\begin{array}{l}\text { Amenorrhea ( } 3 \text { years), } \\
\text { acromegaly, hypogonadism }\end{array}$ \\
\hline 21 & $\begin{array}{l}\text { Jankowski et al } \\
\text { (6) } 2015\end{array}$ & $14 \mathrm{M}$ & $\begin{array}{l}\text { Headache, nausea, vomiting (6 } \\
\text { days) }\end{array}$ & Photophobia (6 days) & $\begin{array}{l}\text { Weight gain, rapid height } \\
\text { increase, sleep disturbance, } \\
\text { behavioral problems, } \\
\text { dysphoric mood }\end{array}$ \\
\hline 22 & $\begin{array}{l}\text { Jankowski et al } \\
\text { (6) } 2015\end{array}$ & $18 \mathrm{~F}$ & $\begin{array}{l}\text { Headache, nausea, vomiting, } \\
\text { dizziness ( } 15 \text { days) }\end{array}$ & None & Galactorrhea \\
\hline 23 & $\begin{array}{l}\text { Jankowski et al } \\
\text { (6) } 2015\end{array}$ & $16 \mathrm{~F}$ & Headache, dizziness (4 days) & Photophobia (4 days) & $\begin{array}{l}\text { Galactorrhea, amenorrhea, } \\
\text { fatigue }\end{array}$ \\
\hline 24 & $\begin{array}{l}\text { Jankowski et al } \\
\text { (6) } 2015\end{array}$ & $14 \mathrm{M}$ & Headache, dizziness (5 months) & None & Fatigue \\
\hline 25 & $\begin{array}{l}\text { Jankowski et al } \\
\text { (6) } 2015\end{array}$ & $16 \mathrm{~F}$ & Headache, nausea (2 months) & Decreased visual acuity & Galactorrhea \\
\hline 26 & $\begin{array}{l}\text { Jankowski et al } \\
\text { (6) } 2015\end{array}$ & $16 \mathrm{~F}$ & Headache (3 days) & None & Amenorrhea, galactorrhea \\
\hline 27 & $\begin{array}{l}\text { Jankowski et al } \\
\text { (6) } 2015\end{array}$ & $18 \mathrm{~F}$ & Headache, dizziness (5 months) & $\begin{array}{l}\text { Peripheral field deficit } \\
\mathrm{L}>\mathrm{R} \text { ( } 5 \text { months })\end{array}$ & Amenorrhea, galactorrhea \\
\hline 28 & $\begin{array}{l}\text { Jankowski et al } \\
\text { (6) } 2015\end{array}$ & $17 \mathrm{~F}$ & Headache (1 year) & $\begin{array}{l}\text { Peripheral field deficit } \\
\mathrm{L}>\mathrm{R} \text { (5 months) }\end{array}$ & Amenorrhea, galactorrhea \\
\hline 29 & $\begin{array}{l}\text { Kumar and } \\
\text { Sharma } \\
\text { (25) } 2016\end{array}$ & $18 \mathrm{M}$ & Headache, vomiting (5 days) & $\begin{array}{l}\text { Decreased visual acuity } \\
\text { ( } 5 \text { days), bilateral } \\
\text { papilledema, bitemporal } \\
\text { hemianopsy }\end{array}$ & Acromegaly, hypopituitarism \\
\hline 30 & $\begin{array}{l}\text { Özçetin et al } \\
\text { (29) } 2016\end{array}$ & $9 \mathrm{M}$ & $\begin{array}{l}\text { Fever ( } 3 \text { days), vomiting, } \\
\text { somnolence }\end{array}$ & $\begin{array}{l}\text { Progressive loss of vision, } \\
\text { blindness, nerve VI palsy }\end{array}$ & SIADH \\
\hline & Our case & $13 \mathrm{M}$ & $\begin{array}{l}\text { Headache, vomiting, } \\
\text { phonophobia, fever (4 days) }\end{array}$ & None & Fatigue, hypopituitarism \\
\hline
\end{tabular}

therapy, indicating that corticotropic deficiency is commonly seen in young patients with PA. Even if serum cortisol and its response to an ACTH injection appear normal in the acute situation, an ACTH deficiency can become apparent in subsequent days.

Due to the severity of a possible hemodynamic instability seen by an Addisonian crisis, every patient with signs or symptoms of PA should immediately be treated with steroids (4). Our patient immediately received hydrocortisone after hypocortisolism was noticed. In the following days, his clinical condition improved rapidly. However, since antibiotics were also administered, it was hard to say which component of the treatment led to his improvement.

\section{Differentiation Between Pituitary Apoplexy Originating from Adenoma and Pituitary Abscess}

The differentiation between PA and pituitary abscess is of vital importance because of the contrasting therapeutic consequences: pituitary abscess is an indication for immediate operation, while an expectative policy would usually be the best option in patients with PA. Based on the literature, four 
elements are discussed for the differential diagnosis between PA and pituitary abscess: 1) Clinical presentation, 2) Infection parameters, 3) Endocrine function, 4) Neuroimaging.

\section{Clinical Presentation}

Liu et al (7) described the largest series (33 patients; mean age 42 years; range 12 to 63 years) of patients with pituitary abscess so far. In their cohort, the most common clinical symptoms were headache $(70 \%)$, with no common pattern, and visual disturbances $(27 \%)$. Headache with a sudden onset can also occur in patients with pituitary abscess (32). In the reports on young individuals we reviewed, headache was also the most common described symptom $(90 \%)$, with a sudden onset in one third of them. Despite the frequently described sudden onset, no common pattern of headache was observed. Visual disturbances were described in $73 \%$ of cases.

Regarding the strong clinical similarities between PA and pituitary abscess, no differentiation between these two conditions could be made based on clinical presentation.

Furthermore a low 'PA Score' (0 out of 10 points), based on the absence of visual symptoms and his normal level of consciousness (33), was found in our patient. This clinical tool did not help us differentiate the two conditions.

\section{Infection Parameters}

Initial laboratory results demonstrated a normal white blood cell count, an elevated serum CRP, and hypoglycemia in our patient, which together with the elevated body temperature was initially considered highly suggestive of pituitary abscess. However, in the literature, a 57-year-old man was described with a presentation similar to that of our patient (34). In that patient, there was a strong suspicion of bacterial meningoencephalitis due to the combination of fever, meningeal irritation, elevated CRP (109 mg/L), and neutrophilic leukocytosis $\left(13.600 / \mathrm{mm}^{3}, 66 \%\right.$ neutrophils). MRI imaging showed a sellar mass which initially was defined as a secondary pituitary abscess. However, cerebrospinal fluid contained no microbes, and during surgery, biopsy was obtained that demonstrated PA originating from an adenoma. Also, the presence of fever appears to have a low discriminative power, since this was reported in one third of the cases in young individuals with PA in $18 \%$ of patients with pituitary abscess (7). Despite the difference in age in comparison with our patient, we conclude that a very elevated CRP, leukocytosis, and fever can also occur in PA.

\section{Endocrine Function}

Our patient's endocrine analysis demonstrated hypopituitarism. This endocrine condition was reported in $26 \%$ of the reviewed cases and in $85 \%$ of cases with pituitary abscess (7). In patients with pituitary abscess, $70 \%$ presented with DI (7). In contrast, less than $5 \%$ of the cases with PA described by Briet et al (4) presented with DI and none of the reviewed were young cases. DI is a condition that usually develops after pituitary surgery (35). It is noteworthy that DI may be masked by secondary adrenal failure and develop after steroid or thyroid replacement. From the reviewed cases, seven ( $23 \%$ ) developed DI - five of them were operated and 2 were treated conservatively (Table 3 ). Persistent DI was described in 3 cases and transient - in 1. Description of DI in the other 3 cases is inconclusive. Eight of nine cases originally described by Jankowski et al (6) are included in our study. Four of them developed transient DI and 1 developed persistent DI. DI after conservative treatment of PA has sporadically been documented in the literature. Only two non-surgically treated cases included in our group developed DI $(13,18)$.

We conclude that endocrine function tests are necessary but can hardly assist in differentiating PA from pituitary abscess.

\section{Neuroimaging}

The MRI showed a space-occupying lesion at the site of the sella turcica in our patient.

The typical cystic features of pituitary abscess are hypointense on T1WI but hyperintense on T2WI. Rim enhancement can be seen after gadolinium in $64 \%$ of pituitary abscesses (7). The remaining $36 \%$ had hypointense to isointense signaling on T1 WI and isointense to hyperintense signaling on T2WI. The MRI performed in our patient showed a heterogeneous hyperintense signal on T1WI, hypointense to isointense signal on T2WI with rim enhancement after gadolinium, as well as sphenoid sinus mucosal thickening. These $\mathrm{T} 1 \mathrm{WI}$ and T2WI features were consistent with a hemorrhage (36), although rim enhancement after gadolinium is more often seen in pituitary abscess $(64 \%)$ than in PA $(36 \%)$.

In our reviewed young patients, all MRI findings were suggestive of hemorrhage within an adenoma. Also, compression of the surrounding structures was stated in 15 cases, involving the optic chiasm in 14, the infundibulum in 4 , and the hypothalamus in one. Furthermore, sphenoid sinus mucosal thickening was observed in our patient, a finding that could suggest an inflammation of the sinus and may constitute a potential cause of a secondary pituitary abscess $(37,38)$. However, mucosal thickening was also seen in 2 of the 9 adolescent patients with PA investigated by Jankowski et al (6) and is probably due to venous engorgement secondary to PA. Thus, when a patient has 
Table 3. Summary of pathological characteristics, treatment and follow-up data of cases younger than 20 years with pituitary apoplexy

\begin{tabular}{|c|c|c|c|c|}
\hline $\begin{array}{l}\text { Case } \\
\text { no. }\end{array}$ & $\begin{array}{l}\text { Adenoma } \\
\text { type }\end{array}$ & Surgery & Residual symptoms and endocrine sequelae & $\begin{array}{l}\text { Endocrine } \\
\text { replacement }\end{array}$ \\
\hline 1 & Unknown & - & Normal vision, ophthalmoplegia and hemiparesis resolved & Unknown \\
\hline 3 & $\mathrm{GH}$ & + & DI, improved vision and pupil response of left eye, blindness of right eye & Unknown \\
\hline 4 & $\mathrm{GH}+\mathrm{PRL}$ & + & DI, vision recovered, growth faltering, hypopituitarism & + \\
\hline 6 & PRL & + & Impaired menses & + \\
\hline 7 & $\mathrm{GH}$ & - & $\begin{array}{l}\text { DI, acromegaly facial symptoms and galactorrhea resolved, } \\
\text { hypopituitarism }\end{array}$ & + \\
\hline 8 & Unknown & - & $\begin{array}{l}\text { Gradual improvement of condition, DI, ophthalmoplegia and facial } \\
\text { paresis resolved, hypopituitarism }\end{array}$ & + \\
\hline 11 & PRL & + & Endocrine and subjective symptoms improved, hypopituitarism & Unknown \\
\hline 12 & $\mathrm{GH}+\mathrm{PRL}$ & + & Vision improved, normal pituitary function & - \\
\hline 13 & PRL & - & Resolved functional and ophthalmic signs, hypopituitarism & + \\
\hline 14 & NFA & + & Symptoms improved pre-operatively, DI, hypopituitarism & + \\
\hline 15 & ACTH & - & Cushing's and subjective symptoms resolved, hypopituitarism & + \\
\hline 16 & PRL & - & Normal pubertal development, panhypopituitarism & + \\
\hline 17 & NFA & + & Improvement of vision and field defects, headache resolved & + \\
\hline 23 & PRL & + & $\begin{array}{l}\text { Normal pituitary function, headaches, mood disturbance and anxiety, } \\
\text { photophobia resolved }\end{array}$ & - \\
\hline 24 & PRL & + & No residual symptoms, normal pituitary function & - \\
\hline 25 & PRL & + & No residual symptoms, normal pituitary function, normal visual acuity & - \\
\hline 26 & PRL & + & No residual symptoms, normal pituitary function & - \\
\hline 27 & PRL & + & $\begin{array}{l}\text { No residual symptoms, normal pituitary function, slight improvement of } \\
\text { visual fields }\end{array}$ & - \\
\hline 28 & PRL & + & $\begin{array}{l}\text { Mild intermittent headaches, normal pituitary function, slight } \\
\text { improvement of visual fields }\end{array}$ & - \\
\hline 29 & $\mathrm{GH}$ & - & No residual symptoms, normal visual fields & + \\
\hline 30 & $\mathrm{GH}$ & + & DI, hypopituitarism & + \\
\hline $\begin{array}{l}\text { Our } \\
\text { case }\end{array}$ & NFA & - & No residual symptoms, hypopituitarism & + \\
\hline
\end{tabular}


either PA or pituitary abscess, the differentiation should be made by MRI neuroimaging. Clinical presentation, PA Score, infection parameters, and endocrine function are not helpful in the differentiation of these two conditions. In our patient, based on the MRI neuroimaging findings, PA was more likely than pituitary abscess.

\section{Treatment}

We did not find any publication comparing the outcome of different therapeutic strategies in patients with PA younger than 20 years. In adults, Singh et al (39) analyzed the outcomes of case series of different treatment options of PA (57 males; 30 females; mean age 51 years; range 15 to 91 years). They concluded that the outcome of most patients was excellent and that no statistically significantly differences existed between the surgically and conservatively treated patients. All patients with endocrine deficiencies or electrolyte disturbances were acutely managed with hormonal and electrolytes substitution. Most of the patients who received early surgery (surgery within a median time of 5 days, range 3 to 10 days) had severe neuroophthalmological deficits at presentation. On the other hand, patients who lacked severe neuro-ophthalmological deficits, including patients with reduced consciousness, or patients with a rapid response to acute management, were adequately managed conservatively. In line with this advice, our patient was not subjected to a surgical intervention because of his rapid clinical improvement with antibiotics, hydrocortisone, and levothyroxine substitution.

Out of the 30 reported young cases, 23 underwent surgery, mostly via the transsphenoidal route $(78 \%)$. Nine of these patients received endocrine replacement therapy. Of these 9 patients, 1 died shortly after surgery and there was no mention of symptom relief in 5 . Seven cases were managed conservatively, of whom 6 received endocrine replacement therapy.

Our patient received prolonged endocrine replacement therapy due to persisting hormonal deficiencies and this was also seen in 15 reported cases (50\%), illustrating the high risk of permanent damage of the pituitary gland caused by PA.

\section{Conclusions}

$\mathrm{PA}$ is a rare condition seen in patients younger than 20 years, but must be considered when a patient experiences headache with or without visual disturbances, even in the presence of clinical or laboratory findings suggestive of an infection. There should be a high index of suspicion for ACTH deficiency which must be promptly treated with stress doses of hydrocortisone. Differentiation between pituitary abscess and PA is difficult. Type of headache, elevated CRP, endocrinological status, and fever do not differentiate between the two conditions. MRI neuroimaging is helpful in making the diagnosis since differences exist in T1W1 and T2W1 images of patients with hemorrhage and abscess. We agree with Singh et al (39) that without severe neuroophthalmological deficits or with a quick response to the acute management, patients can be treated conservatively. Furthermore, multiple persistent pituitary deficiencies, including DI, are a common outcome.

\section{Acknowledgements}

We thank Dr. D.A.J.P. Haring, pediatrician in the Alrijne Hospital (Leiden) for referring the patient to our hospital and for providing clinical and laboratory information.

\section{Ethics}

Informed Consent: Written informed consent for publication of the data was given by the patient and his parents.

Peer-review: Externally peer-reviewed.

\section{Authorship Contributions}

Concept: Hero Zijlker, Design: Wilma Oostdijk, Jan Maarten Wit, Nienke Biermasz, Wouter van Furth, Sebastian Schagen, Data Collection and Processing: Hero Zijlker, Analysis and Interpretation: Hero Zijlker, Wilma Oostdijk, Literature Research: Hero Zijlker, Writing: Hero Zijlker.

Financial Disclosure: The authors declared that this study received no financial support.

\section{References}

1. Keil MF, Stratakis CA. Pituitary tumors in childhood: update of diagnosis, treatment and molecular genetics. Expert Rev Neurother 2008;8:563-574.

2. Mindermann T, Wilson CB. Pediatric pituitary adenomas. Neurosurgery 1995;36:259-269

3. Oldfield EH, Merrill MJ. Apoplexy of pituitary adenomas: the perfect storm. J Neurosurg 2015;122:1444-1449.

4. Briet C, Salenave S, Bonneville JF, Laws ER, Chanson P. Pituitary Apoplexy. Endocr Rev 2015;36:622-645. Epub 2015 Sep 28

5. Dawson BH, Kothandaram P. Acute massive infarction of pituitary adenomas. A study of five patients. J Neurosurg 1972;37:275-279.

6. Jankowski PP, Crawford JR, Khanna P, Malicki DM, Ciacci JD, Levy ML. Pituitary tumor apoplexy in adolescents. World Neurosurg 2015;83:644-651. Epub 2014 Dec 18

7. Liu F, Li G, Yao Y, Yang Y, Ma W, Li Y, Chen G, Wang R. Diagnosis and management of pituitary abscess: experiences from 33 cases. Clin Endocrinol (Oxf) 2011;74:79-88.

8. Schönbeck Y, Talma H, van Dommelen P, Bakker B, Buitendijk SE, HiraSing RA, van Buuren S. The world's tallest nation has stopped growing taller: the height of Dutch children from 1955 to 2009. Pediatr Res 2013;73:371-377. Epub 2012 Dec 10 
9. Cole TJ, Roede MJ. Centiles of body mass index for Dutch children aged 0-20 years in 1980--a baseline to assess recent trends in obesity. Ann Hum Biol 1999;26:303-308.

10. Kinoshita Y, Tominaga A, Usui S, Arita K, Sakoguchi T, Sugiyama K, Kurisu K. Pituitary adenomas in childhood and adolescence with a focus on intratumoral hemorrhage. Pituitary 2014;17:1-6.

11. Sugita S, Hirohata M, Tokutomi T, Yamashita M, Shigemori M. A case of pituitary apoplexy in a child. Surg Neurol 1995;43:154-157.

12. Arisaka O, Hall R, Hughes IA. Spontaneous endocrine cure of gigantism due to pituitary apoplexy. Br Med J (Clin Res Ed) 1983;287:1007-1008.

13. Dourakis SP, Papanikolaou IS, Kontogeorgos G, Tolis G. Pituitary nonsecreting macroadenoma apoplexy in an adolescent, patient report and review of the literature. J Pediatr Endocrinol Metab 2002;15:15491552 .

14. Kamboj MK, Zhou P, Molofsky WJ, Franklin B, Shah B, David R, Kohn B. Hemorrhagic pituitary apoplexy in an 18 year-old male presenting as non-ketotic hyperglycemic coma (NKHC). J Pediatr Endocrinol Metab 2005; 18:611-615.

15. Kaplan B, Day AL, Quisling R, Ballinger W. Hemorrhage into pituitary adenomas. Surg Neurol 1983;20:280-287.

16. Knoepfelmacher M, Gomes MC, Melo ME, Mendonca BB. Pituitary apoplexy during therapy with cabergoline in an adolescent male with prolactin-secreting macroadenoma. Pituitary 2004;7:83-87.

17. Kulah A, Erel C, Memis M, Sav A. Arrested puberty associated with apoplectic prolactinoma in a male adolescent. Childs Nerv Syst 1995; 11:124-127.

18. Mizutani T, Teramoto A, Aruga T, Takakura K, Sanno N. Prepubescent pituitary null cell macroadenoma with silent macroscopic apoplexy: case report. Neurosurgery 1993;33:909-910.

19. Pinto G, Zerah M, Trivin C, Brauner R. Pituitary apoplexy in an adolescent with prolactin-secreting adenoma. Horm Res 1998;50:38-41.

20. Rovit RL, Fein JM. Pituitary apoplexy: a review and reappraisal. J Neurosurg 1972;37:280-288.

21. Sakalas R, David RB, Vines FS, Becker DP. Pituitary apoplexy in a child. Case report. J Neurosurg 1973;39:519-522.

22. Satyarthee GD, Mahapatra AK. Pituitary apoplexy in a child presenting with massive subarachnoid and intraventricular hemorrhage. J Clin Neurosci 2005; 12:94-96.

23. Vidal E, Cevallos R, Vidal J, Ravon R, Moreau JJ, Rogues AM, Loustaud $\mathrm{V}$, Liozon F. Twelve cases of pituitary apoplexy. Arch Intern Med 1992;152:1893-1899.

24. Wang XL, Dou JT, Lü ZH, Zhong WW, Ba JM, Jin D, Lu JM, Pan CY, $\mathrm{Mu}$ YM. Spontaneous remission of acromegaly or gigantism due to subclinical apoplexy of pituitary growth hormone adenoma. Chin Med J (Engl) 2011;124:3820-3823.
25. Kumar S, Sharma S. Pituitary apoplexy causing spontaneous remission of acromegaly following long-acting octreotide therapy: a rare drug side effect or just a coincidence. Oxf Med Case Reports 2016;2016:81-83.

26. Pozzati E, Frank G, Nasi MT, Giuliani G. Pituitary apoplexy, bilateral carotid vasospasm, and cerebral infarction in a 15-year-old boy. Neurosurgery 1987;20:56-59.

27. Lever EG, Butler J, Moore P, Cox TC, Maccabe JJ. Infarction of a growth hormone-secreting macroadenoma during a TRH test. Acta Endocrinol (Copenh) 1986;112:172-179.

28. Rotman-Pikielny P, Patronas N, Papanicolaou DA. Pituitary apoplexy induced by corticotrophin-releasing hormone in a patient with Cushing's disease. Clin Endocrinol (Oxf) 2003;58:545-559.

29. Özçetin M, Karacı M, Toroslu E, Edebali N. A pediatric case of pituitary macroadenoma presenting with pituitary apoplexy and cranial nerve involvement: case report. Turk Pediatri Ars 2016;51:162-165.

30. Balarini Lima GA, Machado Ede O, Dos Santos Silva CM, Filho PN, Gadelha MR. Pituitary apoplexy during treatment of cystic macroprolactinomas with cabergoline. Pituitary 2008;11:287-292.

31. Abe T, Ludecke DK, Saeger W. Clinically nonsecreting pituitary adenomas in childhood and adolescence. Neurosurgery 1998;42:750751.

32. Vates GE, Berger MS, Wilson CB. Diagnosis and management of pituitary abscess: a review of twenty-four cases. J Neurosurg 2001;95:233-241.

33. Rajasekaran S, Vanderpump M, Baldeweg S, Drake W, Reddy N, Lanyon M, Markey A, Plant G, Powell M, Sinha S, Wass J. UK guidelines for the management of pituitary apoplexy. Clin Endocrinol (Oxf) 2011;74:920.

34. Huang WY, Chien YY, Wu CL, Weng WC, Peng TI, Chen HC. Pituitary adenoma apoplexy with initial presentation mimicking bacterial meningoencephalitis: a case report. Am J Emerg Med 2009;27:517.

35. Randeva HS, Schoebel J, Byrne J, Esiri M, Adams CB, Wass JA. Classical pituitary apoplexy: clinical features, management and outcome. Clin Endocrinol (Oxf) 1999;51:181-188.

36. Piotin M, Tampieri D, Rufenacht DA, Mohr G, Garant M, Del Carpio R, Robert F, Delavelle J, Melanson D. The various MRI patterns of pituitary apoplexy. Eur Radiol 1999;9:918-923.

37. Chong VF, Fan YF. Comparison of CT and MRI features in sinusitis. Eur J Radiol 1998;29:47-54

38. Shono T, Nishio S, Muratani H, Yasuda T, Fukui M, Moutai K. Pituitary abscess secondary to isolated sphenoid sinusitis. Minim Invasive Neurosurg 1999;42:204-206.

39. Singh TD, Valizadeh N, Meyer FB, Atkinson JL, Erickson D, Rabinstein AA. Management and outcomes of pituitary apoplexy. J Neurosurg 2015;122:1450-1457. Epub 2015 Apr 10 